University of Nebraska - Lincoln

DigitalCommons@University of Nebraska - Lincoln

Public Health Resources

Public Health Resources

1997

\title{
THE ETIOLOGY OF NEURAL TUBE DEFECTS
}

J. M. Scott

University of Dublin, Trinity College

D. G. Weir

University of Dublin, Trinity College

A. Molloy

University of Dublin, Trinity College

J. McPartlin

University of Dublin, Trinity College

Leslie Daly

University College Dublin, Ireland

See next page for additional authors

Follow this and additional works at: https://digitalcommons.unl.edu/publichealthresources

Part of the Public Health Commons

Scott, J. M.; Weir, D. G.; Molloy, A.; McPartlin, J.; Daly, Leslie; Kirke, P.; Conley, M.; Lee, J.; and Mills, J., "THE ETIOLOGY OF NEURAL TUBE DEFECTS" (1997). Public Health Resources. 208.

https://digitalcommons.unl.edu/publichealthresources/208

This Article is brought to you for free and open access by the Public Health Resources at DigitalCommons@University of Nebraska - Lincoln. It has been accepted for inclusion in Public Health Resources by an authorized administrator of DigitalCommons@University of Nebraska - Lincoln. 


\section{Authors}

J. M. Scott, D. G. Weir, A. Molloy, J. McPartlin, Leslie Daly, P. Kirke, M. Conley, J. Lee, and J. Mills 


\section{HOMOCYSTEINE \\ METABOLISM: FROM \\ BASIC SCIENCE TO \\ CLINICAL MEDICINE}

Editors

Ian Graham, MD

THE ADELAIDE HOSPITAL

TRINITY COLLEGE

DUBLIN

IRELAND

Helga Refsum, MD

UNIVERSITY OF BERGEN

DEPARTMENT OF CLINICAL BIOLOGY

BERGEN

NORWAY

Irwin H. Rosenberg, MD

JEAN MAYER USDA HUMAN NUTRITION RESEARCH

CENTER ON AGING AT TUFTS UNIVERSITY

BOSTON, MA

USA

Per Magne Ueland, MD

UNIVERSITY OF BERGEN

DEPARTMENT OF CLINICAL BIOLOGY

BERGEN

NORWAY

Scientific Editor:

Jill M. Shuman, MS, RD, ELS

TUFTS UNIVERSITY SCHOOL OF

NUTRITION SCIENCE AND POLICY MEDFORD, MA

$$
\text { USA }
$$

Kluwer Academic Publishers

BOSTON DORDRECHT LONDON 
J.M. Scott

Trinity College

Department of Biochemistry

University of Dublin

Dublin, Ireland

D.G. Weir

Trinity College

Dublin, Ireland

\section{A. Molloy \\ Trinity College \\ Dublin, Ireland}

J. McPartlin
Trinity College
Dublin, Ireland

Leslie Daly

Department of Public Health, Medicine, and Epidemiology

University College

Dublin, Ireland

P. Kirke

Health Research Board

Dublin, Ireland

M. Conley

National Institutes of Health

Bethesda, MD, USA

J. Lee

National Institutes of Health

Bethesda, MD, USA

J. Mills

National Institutes of Health

Bethesda, MD, USA 


\title{
18. THE ETIOLOGY OF NEURAL TUBE DEFECTS
}

\author{
J.M. Scott, D.G. Weir, A. Molloy, J. McPartlin, L. Daly, P. Kirke, M. Conley, \\ J. Lee, and J. Mills
}

\section{Introduction}

Evidence continues to confirm that periconceptional ingestion of folic acid can prevent neural tube defects, although the basis of this prevention has been unclear. To further elucidate the mechanism by which this occurs, blood samples were collected from more than 50,000 pregnant women and the samples analyzed for red cell folate, plasma folate, plasma vitamin $B_{12}$, and plasma homocysteine levels. Based on the results, it appears that the beneficial effect of folic acid is in overcoming a metabolic block in a folatedependent enzyme or transport process. It is likely that methionine synthase may be directly or indirectly involved.

The neural plate closes to form the spinal cord and the cranium between days 24 and 28 postconception. Incomplete closure of the former causes spina bifida; of the latter, anencephaly. The two conditions are called neural tube defects (NTD) [1]. Earlier evidence that folic acid taken periconceptionally by women could prevent NTDs [2-4] has recently been confirmed by two randomized trials using periconceptional ingestion of folic acid supplements $[5,6]$.

There are three possible ways by which folic acid might exert this protective effect: (1) it might treat folate deficiency; (2) it might overcome malabsorption; or, (3) it might overcome a metabolic block. The future public health response to this important development would depend to a considerable extent on which one of these three mechanisms is actually involved. If simple folate deficiency is involved, protection might be achieved at levels of folic acid far lower than the $400 \mu \mathrm{g}$ per day used in the trials. By contrast, if folic acid overcomes malabsorption or an impairment or block in some folate-dependent enzyme or process, the relatively high levels of folic acid used in the trials may be essential to achieve protection.
We set out to test which of the three was the operative alternative by collecting blood samples from women early in pregnancy, when their folate status would most accurately reflect that pertaining to the time of closure of the neural tube (days 24-28 postconception). When it was subsequently ascertained which women had an NTD-affected pregnancy, blood samples were retrieved and their plasma and red cell folates (RCFs) were compared with controls matched for length of storage. We further investigated evidence that a metabolic block in folate metabolism actually existed in these women.

\section{Materials and Methods}

Between March 1986 and March 1990 more than 50,000 blood samples were collected at the first booking clinic from women attending the three Dublin Maternity Hospitals (Coombe, Rotunda, and National Maternity). These three hospitals carry out most of the deliveries in the greater Dublin area, and the collections represented more than $70 \%$ of these, giving a very representative cohort. Blood was collected into potassium EDTA. A sample of this whole blood was taken and diluted 1 in 10 into $1 \%$ ascorbic acid in water for RCF analysis [7]. Plasma was separated by centrifugation. All samples were stored at $-20^{\circ} \mathrm{C}$ until analyzed. For the study, samples from the women who had an NTD-affected pregnancy (cases) were identified and retrieved. Samples were also identified from a randomly selected group of women with normal pregnancy outcomes (controls) taken over the same period and in the same hospitals. This resulted in 81 cases and 247 controls on which an analysis for RCF and plasma folate was carried out [7]. Plasma vitamin $B_{12}$ levels were also estimated on these samples [8]. Plasma homocysteine levels were assayed by a modification of a previous method [9]. 


\section{Results}

For plasma folate, the median (range) for the cases was $3.5 \mu \mathrm{g} / \mathrm{L}(0.7-20.8 ; n=81)$ and for controls was $4.6 \mu \mathrm{g} / \mathrm{L}(0.5-22.1 ; n=247)$. Values for cases were significantly lower $(p=0.001)$. Comparable results for RCF in cases were $269 \mu \mathrm{g} / \mathrm{L}(39-715 ; n=81)$ and in controls were $338 \mu \mathrm{g} / \mathrm{L}(80-1302 ; n=247)$. Again, values for cases were significantly lower $(p=0.002)$. Of significance is that only seven cases $(8.6 \%)$ had plasma folate levels that would be considered deficient $(<1.5 \mu \mathrm{g} / \mathrm{L})$ (table 18-1). Similarly, consideration of RCF values in the cases found only 11 $(13.6 \%)$ with deficient values $(<150 \mu \mathrm{g} / \mathrm{L})$. Likewise, it was clear that very few cases $(5(6.1 \%))$ had vitamin $\mathrm{B}_{12}$ levels in the deficient range $(<150 \mathrm{ng} / \mathrm{L})($ table 18.2). Plasma folate levels were found to be a risk factor for an NTD-affected birth [10]. Of greater significance was that plasma vitamin $B_{12}$ levels acted as an independent risk factor for an affected pregnancy. There was also no correlation between the plasma folate level and the plasma vitamin $B_{12}$ level in either cases or controls (fig. 18-1).

TABLE 18-1. Percentage of cases and controls that have "deficient folate status" as determined by the usual criteria for red cell folate and plasma folate deficiency

\begin{tabular}{lcc}
\hline & \multicolumn{2}{c}{ Deficient and normal folate levels } \\
\hline & CASES: $N=81$ & CONTROLs: $N=247$ \\
$\begin{array}{l}\text { Red cell folate } \\
(\mu \mathrm{g} / \mathrm{L})\end{array}$ & & \\
$<150$ & $11(13.6 \%)$ & $7(2.8 \%)$ \\
$>150$ & $70(86.4 \%)$ & $240(97.2 \%)$ \\
$\begin{array}{l}\text { Plasma folate } \\
(\mu \mathrm{g} / \mathrm{L}) \\
<1.5\end{array}$ & $7(8.6 \%)$ & $10(4.0 \%)$ \\
$>1.5$ & $74(91.4 \%)$ & $237(96.0 \%)$ \\
\hline
\end{tabular}

TABLE 18-2. Percentage of cases and controls that have deficient status as determined at two levels of plasma vitamin $B_{12}$

\begin{tabular}{ccc}
\hline & \multicolumn{2}{c}{ Deficient and normal plasma $B_{12}$ levels } \\
\hline & CASES: $N=82$ & CONTROLs: $N=251$ \\
$\begin{array}{l}\text { Plasma } B_{12} \\
(\mathrm{ng} / \mathrm{L})\end{array}$ & & \\
$<150$ & $5(6.1 \%)$ & $8(3.2 \%)$ \\
$>150$ & $77(93.9 \%)$ & $243(96.8 \%)$ \\
$<200$ & $14(17.1 \%)$ & $26(10.4 \%)$ \\
$>200$ & $68(82.9 \%)$ & $225(89.6 \%)$ \\
\hline
\end{tabular}

The plasma homocysteine level was compared between cases and controls. This was done by dividing each into deciles of plasma vitamin $B_{12}$. At the lower vitamin $B_{12}$ levels there were significantly higher plasma homocysteine levels in the cases compared with the controls [11].

\section{DISCUSSION}

There is now conclusive evidence that periconceptional supplementation of women with the vitamin folic acid prevents the vast majority of NTDs [5,6]. It was not clear if this prophylaxis was brought about by treating women who are (1) deficient in folate, (2) overcoming an intestinal malabsorption, or whether (3) the higher level of folic acid intake (an extra $400 \mu \mathrm{g}$ per day) overcomes some as yet unidentified metabolic block in folate metabolism. We determined folate status in women who went on to have an affected child later in their pregnancy. This was done by determining both their plasma folate level and their RCFs and matching them to randomly collected controls from similar women with normal pregnancies collected and stored in a similar manner. In nearly half of the cases and controls, blood was collected before 14 weeks postconception. The third quarter was collected between 14-20 weeks, and the remaining quarter at greater than 21 weeks.

Plasma folate is considered to be a reasonable index of folate status. It is, however, subject to daily fluctuations and changes over days or weeks if there is a significant alteration of folate ingestion. It would thus be difficult to be sure that plasma folate taken some ten to perhaps 20 weeks after the closure of the neural tube (days 24 to 28 ) would reflect folate status at that critical time. By contrast, RCF is recognized as a superb index of average folate status over a protracted period. This is because the folate placed in the red cell is done so exclusively during the period of the production and maturation of the red cell in the bone marrow. During that period the folate contents of all red cells is determined by the plasma folate levels that exist at that time. Once the red cell matures, it neither absorbs any further folate nor loses folate until its destruction, usually at 120 days. Thus, $\mathrm{RCF}$ reflects the average plasma folate level and the average status over the previous seven weeks. Therefore, RCF is considered a very stable indication of folate status.

While the cases in our study had significantly lower plasma and RCF levels than the controls, the important question with regard to the hypothesis being addressed concerns the number of cases that were likely to be folate deficient at the time of closure of the neural tube. While we do not have either 

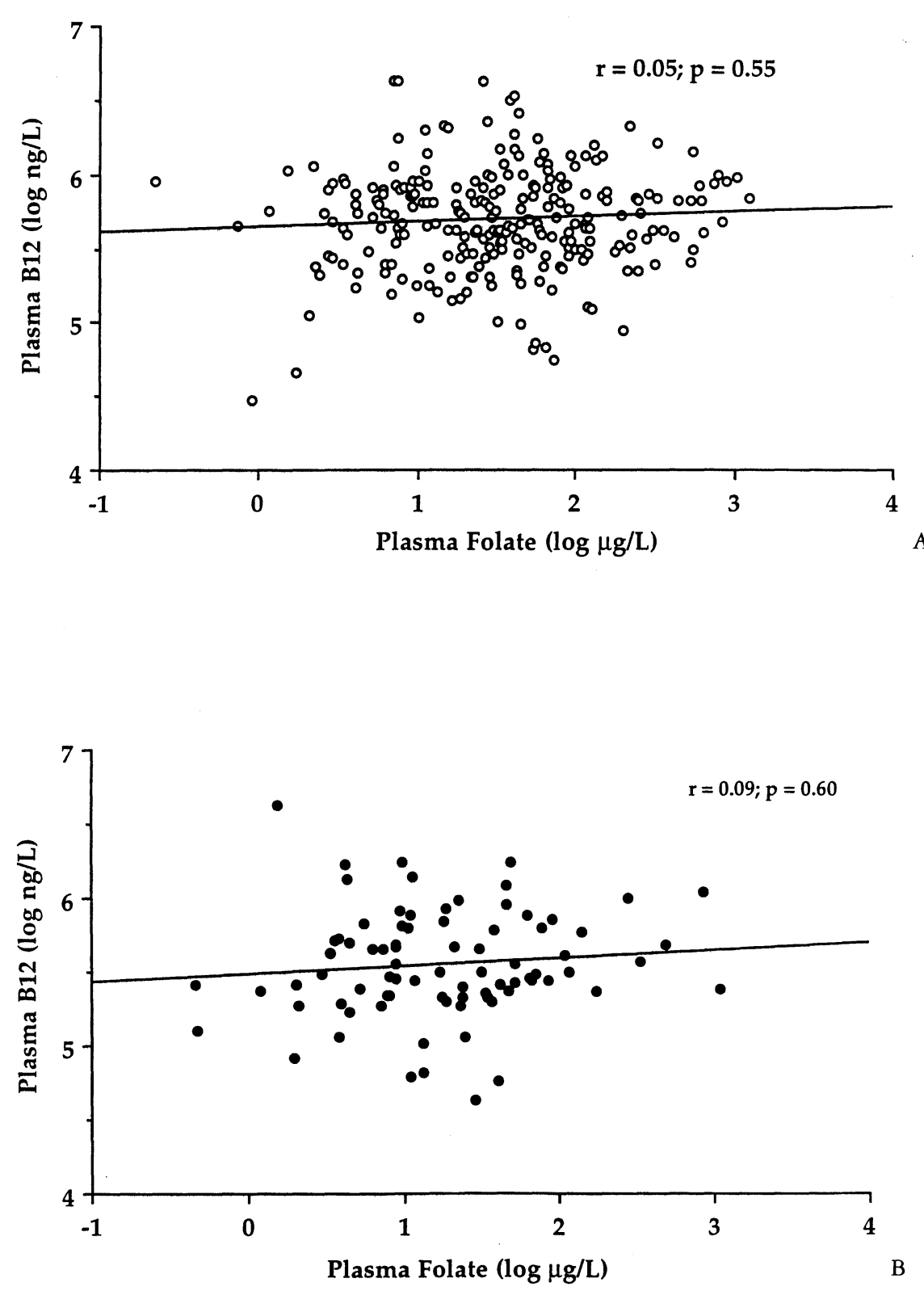

FIGURE 18-1. Regression analysis between log transformed plasma vitamin $\mathrm{B}_{12}$ and $\log$ transformed plasma folate in controls (top) and cases (bottom).

plasma samples or RCF samples taken during that critical, one-month period into pregnancy, it seems reasonable that our RCF values would reflect that earlier status. It can be seen from the results that some $86 \%$ of cases have RCF values in the normal range, indicating that folate deficiency per se is not the cause of NTDs, at least not in the normal meaning of folate deficiency. These findings would also appear to rule out the contention of others $[12,13]$ that intestinal malabsorption of folate is involved in the etiology of NTDs. Were this the case, one would expect this to be reflected in a large number of cases, which clearly they do not (table 18-1). 
Thus, it would appear that the beneficial effect of folic acid is in overcoming a metabolic block in some folate-dependent enzyme or transport process. There are 16 folate-dependent enzymes. We found that, as with folate, almost all of the cases had plasma vitamin $B_{12}$ levels in the normal range, indicating that they were not vitamin $B_{12}$ deficient (table 18-2). However logistic regression analysis showed that the plasma vitamin $B_{12}$ level was an independent risk factor for NTDs. We have shown experimentally that plasma folate and plasma vitamin $B_{12}$ are not correlated either in cases or controls (fig. 18-1); the vitamin $B_{12}$ level is not simply reflecting plasma folate level, which would make it a dependent risk factor. Methionine synthase is the only enzyme that is dependent for its activity on both folate and vitamin $B_{12}$. This would suggest that the activity of methionine synthase is directly or indirectly involved in the development of NTDs. Our finding of an abnormality in homocysteine metabolism in the cases compared with the controls supports the hypothesis that methionine synthase may be directly or indirectly involved [11]. The effect could be direct in that some NTDs might be caused by an abnormal methionine synthase, or indirect in that if there was an abnormality in an enzyme like 5, 10 methylenetetrahydrofolate reductase, variations in activity of the synthase might determine whether a woman would become a case or control.

\section{References}

1. O'Rahilly R, Muller F. Neurulation in the normal human embryo. CIBA Foundation Symposium 181:7089, 1994.

2. Laurence KM, James N, Miller M, Tennant GB, Campbell $\mathrm{H}$. Double-blind randomised controlled trial of folate treatment before conception to prevent recurrence of neural-tube defects. BMJ 282:1509$1511,1981$.

3. Smithells RW, Nevin NC, Seller MJ, Sheppard S, Harris R, Read AP, Fielding DW, Walker S, Schorah CJ, Wild J. Further experience of vitamin supplementation for prevention of neural tube defect recurrences. Lancet i:1027-1031, 1983.

4. Kirke PN, Daly LE, Elwood JH. A randomised trial of low dose folic acid to prevent neural tube defects. Arch Dis Child 67:1442-1446, 1992.

5. Wald N, Sneddon J, Densem J, Frost C, Stone R. MRC Vitamin Study Research Group. Prevention of neural tube defects: Results of the Medical Research Council Vitamin Study. Lancet 338:131-137, 1991.

6. Czeizel AE, Dudas I. Prevention of the first occurrence of neural-tube defects by periconceptional vitamin supplementation. $N$ Engl J Med 327:1832-1835, 1992.

7. O'Broin SD, Kelleher BP. Microbiological assay on microtitre plates of folate in serum and red cells. J Clin Path 45:344-347, 1992.

8. Kelleher BP, O'Broin SD. Microbiological assay for vitamin $\mathrm{B}_{12}$ performed in 96-well microtitre plates. $J$ Clin Path 44:592-595, 1991.

9. Araki A, Sako Y. Determination of free and total homocysteine in human plasma by high performance liquid chromatography with fluorescent detection. $J$ Chromat 422:43-52, 1987.

10. Kirke PM, Molloy AM, Daly LE et al. Maternal plasma folate and vitamin $B_{12}$ are independent risk factors for neural tube defects. Quart J Med 86:703-708,1993.

11. Mills JM, McPartlin JM, Kirke PM et al. Homocysteine metabolism in pregnancies complicated by neural tube defects. Lancet 345:149-151, 1995.

12. Bower CB, Stanley FJ, Croft $M$ et al. Absorption of pteroylpolyglutamates in mothers of infants with neural tube defects. Brit J Nutr 69:827-834, 1993.

13. Wild J, Seller MJ, Schorah CJ, Smithells RW. Investigation of folate intake and metabolism in women who have had two pregnancies complicated by neural tube defects. Brit J Obst Gynaecol 101:197-202, 1994. 